\title{
SUB-NATIONAL INEQUALITY OF CAESAREAN SECTION IN URBAN-RURAL AREA OF INDONESIA
}

\author{
Suparmi $^{1 *}$, Nunik Kusumawardhani ${ }^{1}$ and Kun Arisanti Susiloretni ${ }^{2}$ \\ ${ }^{I}$ National Institute of Health Research and Development, Ministry of Health, Indonesia \\ ${ }^{2}$ Semarang Health Polytechnic, Indonesia
}

\begin{abstract}
Cesarean section is an important indicator of accessibility to the emergency obstetric care. The study aims to examine urban-rural inequality and determinant of caesarean section in Indonesia. Cross-sectional data from national household health survey (RISKESDAS) conducted in 2013 were used. A total of 49,045 aged 15-49 years having live births in the last 3 years preceding the survey was included into the analysis. We report absolute difference and ratio of caesarean rates between urban and rural for each province. The logistic regressions were used to identify determinant of caesarean section. The caesarean section rates in rural and urban were $5.4 \%$ and $13.4 \%$; respectively. Province estimates of caesarean section rates were ranging from $3.1 \%$ in Southeast Sulawesi to $19.1 \%$ in DKI Jakarta. Sub-national inequality between urban and rural among province occurs, accounted for absolute difference between $-0.2 \%$ (West Papua) to $16.2 \%$ (Gorontalo). The logistic regression indicates determinant of caesarean section includes older ages, higher education level, currently employed, living in urban area, living in rich household, had any complication during pregnancy, first child, post-term pregnancy and twin had higher caesarean section rates. This study provides evidence that sub-national inequalities of caesarean section rates between urban and rural in Indonesia remain. These inequalities might due to inadequate access to emergency obstetric care among rural subgroups. Sub-national specific intervention among rural population is deeded to address these inequalities.
\end{abstract}

Keywords: caesarean section, sub-national, inequality, Indonesia

\section{Introduction}

Vaginal birth among pregnant women is considered when there is no identified risk of complication, either for the mothers or their babies(World Health Organization, 2018). When complications occur during pregnancy or labour, a caesarean section is needed as a life-saving surgical procedure(Betrán et al., 2016). However, caesarean section is often performed for various non-medical reasons and lead to short- and long-term health problems(Souza et al., 2010). The caesarean section should be assign as an alternative when vaginal delivery cannot be conducted. However, the current caesarean delivery is not performed only because of medical indications, but because of patient demand.

The caesarean section rates has increased worldwide in the last two decades particularly in Latin America and the Caribbean(Betrán et al., 2016). In Indonesia, the caesarean section rates have significantly increased during the last five years with $6.8 \%$ in 2007 to $12.3 \%$ in 2012(Statistics Indonesia (Badan Pusat Statistik-BPS), National Population and Family Planning Board (BKKBN), Departemen Kesehatan and Macro International., 2008; Statistics Indonesia (Badan Pusat Statistik-BPS) et al., 2013). In result, Indonesia exceed the upper limit of $10 \%$ caesarean section rates in population level, proposed by the World Health Organization(The World Health Organization, 2015). Countries with caesarean section rates above 10 percent do not show any benefit in reducing maternal and neonatal mortality(Ye et al., 2016). Furthermore, high caesarean section rates should be a concern because caesarean sections can cause complications, disability or death particularly in condition of lack health facilities to conduct safe surgery(The World Health Organization, 2015). The decision to choose a caesarean delivery should follow medical procedures based on certain medical indications of the pregnancy. 
Additional concerns and controversies surrounding caesarean section include inequities in the use of the procedure, not only between countries but also within countries and the costs that unnecessary caesarean sections impose on financially stretched health systems(Boatin et al., 2018). In Indonesia, rapid societal development presents a considerable risk for disadvantaged populations to be left behind. There is no clear perspective about how residence differences have contributed towards maternal health intervention in Indonesia, specifically in caesarean section. Subnational analysis should be done because the provinces have local autonomy in the decentralization era, including public health autonomy. The aim of this study is to explore inequality of caesarean section rates stratified by urban-rural and examine socio-demographic determinants of caesarean section in Indonesia.

\section{Methods}

Cross-sectional data from national household health survey (RISKESDAS) conducted in 2013 were used for the analysis. We obtained official permission from the National Institute of Health Research and Development, Ministry of Health for analyzing the data. The RISKESDAS collected data on nutritional status, health services access and utilization, environmental health, infectious and non-communicable diseases, as well as blood subsample.

The survey employed multistage stratified sampling technique. The sampling frame of RISKESDAS 2013 consisted of 12,000 census blocks (cluster) which selected from master sample area from the 2010 population census. In each selected cluster, 25 household were selected from a complete list of households. There were 294,959 households interviewed from a total of 300,000 selected households from the sample, obtained a response rate of $98.3 \%$. The samples were representative from 33 provinces (497 districts/cities) in Indonesia. A total of 1,027,763 household members were interviewed using structured questionnaire and data were collected through interviews by trained enumerators. In this study, we restricted our analysis to women aged 15-49 years having live births in the last 3 years preceding the survey $(n=49,045)$.

The outcome variable was birth occurred by caesarean section. The independent variables consisted of mother's age, mother's education, mother's occupation, place of residence, house hold economic status, complication during pregnancy, parity, term of delivery and weather the delivery twin or not. Maternal age was into 3 subgroups (15-19 years, 20- 34 years, and 35-49 years). Education was based on the last education obtained by the respondent (primary education or less education, secondary education and higher education). High school or above were grouped together into higher education. Working status was divided into unemployed and employed. Place of living was divided into urban and rural.

Household economic status Socio-economic status was an index constructed from household ownership information, using polychoric correlation analysis (PCA). Variables forming the index were: 1) the primary source of drinking water, 2) cooking fuel, 3) defecation facilities ownership, 4) type of toilet, 5) final feces disposal, 6) illumination source, 7) motorcycles, 8) television, 9) water heater, 10) gas cylinder 12 kg, 11) refrigerator, and 12) cars. The index then divided into 5 levels, with quintile 5 as the highest quintile and the lowest or poorest was quintile 1 .

Complication during pregnancy was divided into ever had any complication and none. Term of delivery was divided into 3 subgroups (aterm, preterm and postterm). Women were classified as aterm delivery if they delivered in 9 months of pregnancy; preterm if they had delivery in 7-8 months of pregnancy; and postterm if they had delivery in 10 months of pregnancy.

We compare inequality of absolute difference and ratio between urban and rural using Hear Plus. Descriptive statistics and multilevel logistic regressions were used to identify determinant of caesarean section. The data were analyzed using STATA version 13.0 for windows. The adjusted Odds Ratio with $95 \%$ confidence intervals was calculated in order to assess the strength of association. 


\section{Results}

Table 1 shows the caesarean section rate was substantially higher in urban (13.4\%) compared with rural (5.4\%) and was higher among older mothers (12.0\% for 35-49 yearolds) compared with younger ones (4.4\% for 15-19 year olds and $9.1 \%$ for 20-24 year olds). Caesarean section rates was lowest among mothers with the lowest level of education and increased with increasing education levels, from 5.5\% among mothers with primary or less education to $24.0 \%$ among mothers with higher education. Furthermore, caesarean section rates were lower among mothers from the poorest quintile and increased with increasing economic status, from $2.0 \%$ in quintile 1 to $18.4 \%$ in quintile 5 . The overall difference of caesarean rates between richest and poorest in urban area was $16.4 \%$ and the richest were 9.2 times higher than poorest. The rates were higher among mothers experience with any complication during pregnancy compare to no complication (16.5\% and $8.4 \%$, respectively).

Table 1 Prevalence of caesarean section in urban and rural area of Indonesia, RISKESDAS 2013

\begin{tabular}{|c|c|c|c|}
\hline Characteristics & Total $(95 \%$ CI $)$ & Urban $(95 \%$ CI) & Rural (95\% CI) \\
\hline \multicolumn{4}{|l|}{ Place of residence } \\
\hline Urban & $13.4(12.7-14.1)$ & & \\
\hline Rural & $5.4(5.1-5.9)$ & & \\
\hline \multicolumn{4}{|l|}{ Mother's age } \\
\hline $15-19$ years & $4.4(3.0-6.4)$ & $7.0(4.0-12.0)$ & $2.9(1.8-4.6)$ \\
\hline 20-34 years & $9.1(8.6-9.6)$ & $12.7(11.8-13.6)$ & $5.2(4.7-5.6)$ \\
\hline 35 - 49 years & $12.0(11.2-12.9)$ & $16.6(15.2-18.0)$ & $7.0(6.2-7.8)$ \\
\hline \multicolumn{4}{|l|}{ Mother's education } \\
\hline Primary or less education & $5.5(5.1-5.9)$ & $7.6(6.8-8.5)$ & $4.1(3.7-4.5)$ \\
\hline Secondary education & $13.9(13.0-14.9)$ & $16.2(15.0-17.5)$ & $8.7(7.7-9.8)$ \\
\hline Higher education & $24.0(22.2-25.9)$ & $26.9(24.6-29.3)$ & $15.1(12.7-17.8)$ \\
\hline \multicolumn{4}{|l|}{ Mother's occupation } \\
\hline Unemployed & $8.9(8.4-9.4)$ & $11.8(10.9-12.6)$ & $5.4(4.9-5.9)$ \\
\hline Employed & $11.1(10.3-11.8)$ & $17.3(16.0-18.8)$ & $5.6(5.0-6.2)$ \\
\hline \multicolumn{4}{|l|}{ Household economic status } \\
\hline Quintile 1 & $2.0(1.7-2.4)$ & $2.6(1.7-4.1)$ & $1.9(1.5-2.3)$ \\
\hline Quintile 2 & $4.4(3.9-5.1)$ & $5.3(4.2-6.8)$ & $4.0(3.4-4.8)$ \\
\hline Quintile 3 & $7.7(6.9-8.6)$ & $8.7(7.4-10.2)$ & $6.6(5.7-7.6)$ \\
\hline Quintile 4 & $12.0(11.1-12.9)$ & $13.5(12.4-14.7)$ & $8.5(7.4-9.8)$ \\
\hline Quintile 5 & $18.4(17.2-19.7)$ & $21.0(19.5-22.5)$ & $10.8(9.4-12.4)$ \\
\hline \multicolumn{4}{|l|}{ Complication during pregnancy } \\
\hline None & $8.4(8.0-8.8)$ & $11.9(11.2-12.7)$ & $4.6(4.2-5.0)$ \\
\hline Any complication & $16.5(15.1-18.0)$ & $21.3(19.1-23.8)$ & $10.7(9.5-12.1)$ \\
\hline \multicolumn{4}{|l|}{ Parity } \\
\hline 1 & $11.2(10.3-12.1)$ & $14.8(13.5-16.2)$ & $6.5(5.7-7.5)$ \\
\hline $2-3$ & $9.5(8.9-10.1)$ & $13.4(12.4-14.4)$ & $5.3(4.8-5.9)$ \\
\hline$\geq 4$ & $7.5(6.8-8.3)$ & $11.0(9.7-12.5)$ & $4.4(3.8-5.1)$ \\
\hline \multicolumn{4}{|l|}{ Pregnancy } \\
\hline Aterm & $8.9(8.3-9.6)$ & $12.8(11.8-14.0)$ & $5.0(4.5-5.5)$ \\
\hline Preterm & $10.1(9.5-10.7)$ & $13.7(12.8-14.7)$ & $5.8(5.3-6.4)$ \\
\hline Postterm & $15.4(10.8-21.4)$ & $22.2(14.1-33.3)$ & $8.8(5.4-14.0)$ \\
\hline
\end{tabular}


Twin

No

$9.3(8.9-9.8)$

$13.1(12.4-13.8)$

$5.2(4.8-5.6)$

Yes

$29.6(23.6-36.5)$

$35.3(26.3-45.5)$

$23.0(16.1-31.5)$

Overall, the caesarean section rate in Indonesia was 9.8\%. The rates varied by geographic, socio-economic, and demographic factors as shown in tables 1 and Figure1. Figure 2 shows provincial caesarean section rates on a map. Provinces in the eastern part of Indonesia tended to report higher caesarean section rates than provinces in the west. The caesarean section rates varied between provinces, ranging from $3.1 \%$ in Southeast Sulawesi to $19.1 \%$ in DKI Jakarta.

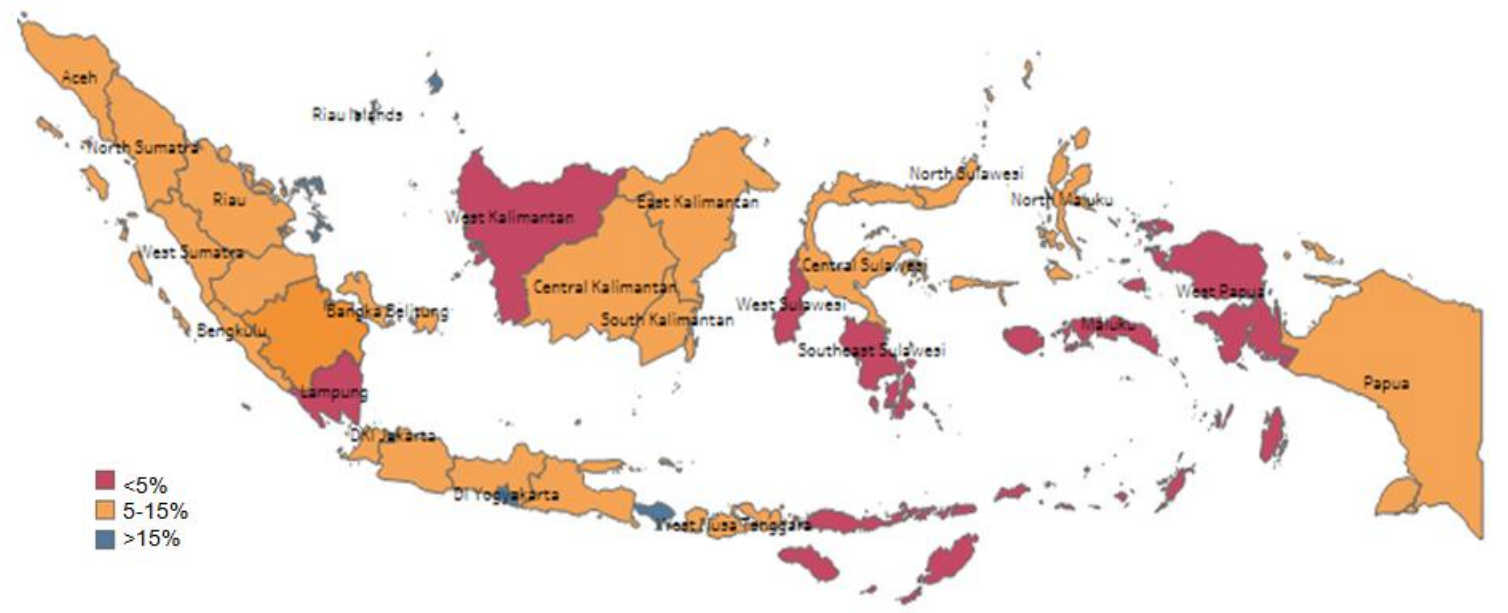

Figure 1 Caesarean section rates by Province, Indonesia, RISKESDAS 2013

Figure 2 shows provincial inequality of caesarean section rates between urban and rural. Bali likely overuse caesarean section reported the prevalence for $17.8 \%$ point estimates and had wide gap between urban and rural (8.5\%). Papua had low caesarean section rates provincial average $(5.5 \%)$ and wide inequality, accounted for $13.7 \%$ point difference between urban and rural. The neighboring province, Maluku reported lower caesarean section rates $(3.5 \%)$. However, the inequality between urban and rural in Maluku nearly twice compare to Papua. Furthermore, the inequality did not see any pattern between eastern and western provinces.

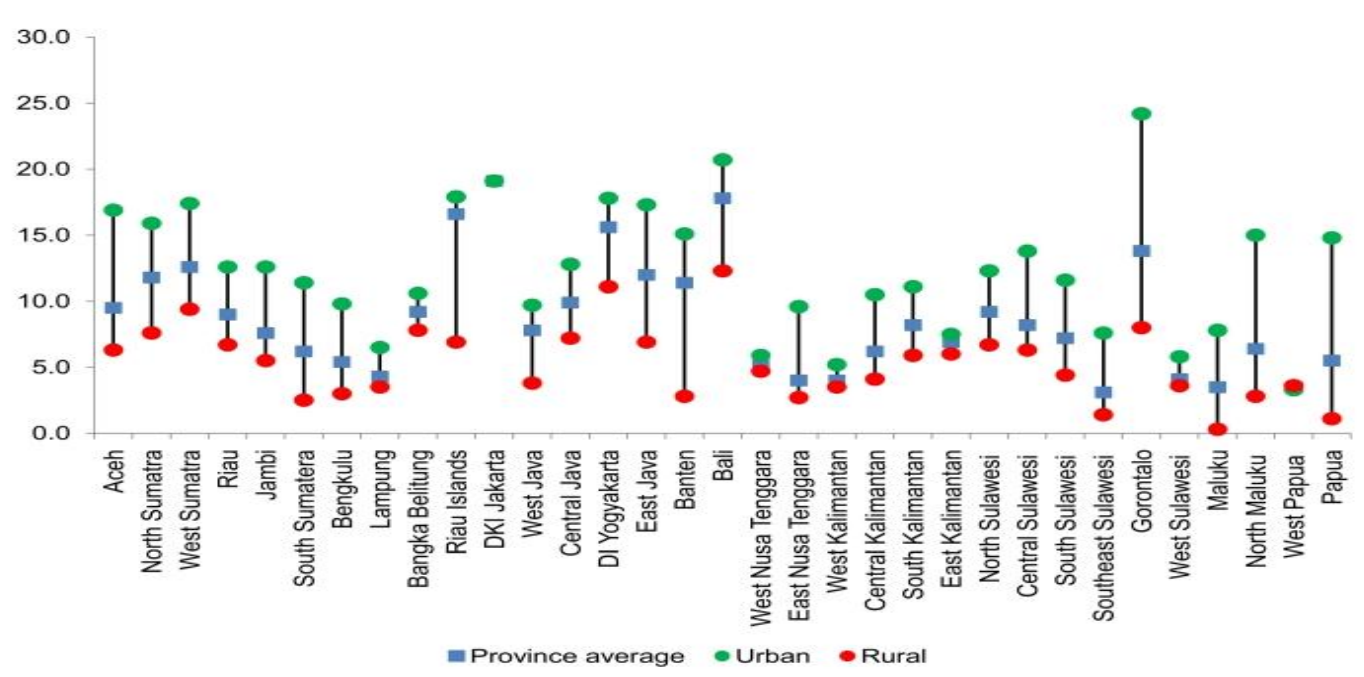

Figure 2:Urban and rural inequality of caesarean section rates by Province, Indonesia, RISKESDAS 2013

Figure 3 shows scatter plots of subnational cesarean section rates and urban-rural inequality. The subnational inequality between urban and rural accounted for absolute difference between $-0.2 \%$ (West Papua) to $16.2 \%$ 
(Gorontalo). West Papua, West Kalimantan, East Kalimantan, West Sulawesi and Lampung had the lowest inequality compare to other province. However, those provinces also encounter low caesarean section rates.

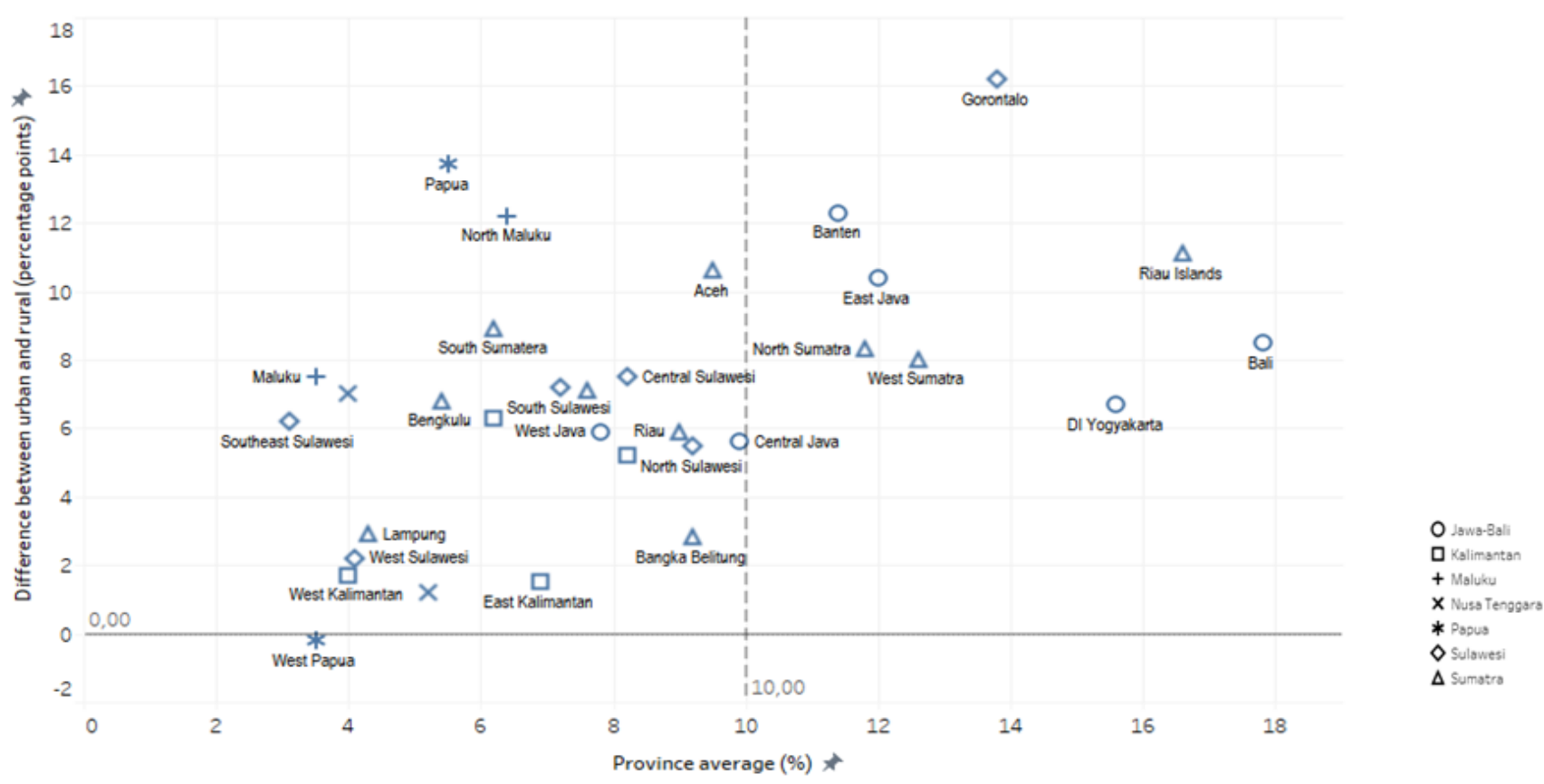

Figure 3: Scatter plots of subnational cesarean section rates and urban-rural inequality (difference between urban and rural) in Indonesia, RISKESDAS 2013

Table 2 presents the adjusted odds ratios from the logistic regression analysis in urban and rural area. The results show that caesarean section rates associated with household economic status. Mothers from the quintiles 4 and 5 had more than three times the odds of caesarean section from the lowest quintile (OR $=3.50$ for quintile 4 and $\mathrm{OR}=4.98$ for quintile 5), while mothers from quintiles 2 and 3 had more than 1.5 times the odds of caesarean section compared with mothers from the lowest quintile $(\mathrm{OR}=1.82$ for quintile 1 and $\mathrm{OR}=2.57$ for quintile 3 ). There was no evidence for a statistically significant association between caesarean section and mother's occupation.

Table 2 Adjusted association between caesarean section and socio-demographic in urban and rural, Indonesia, RISKESDAS 2013

\begin{tabular}{|c|c|c|c|c|c|c|}
\hline \multirow{2}{*}{ Characteristics } & \multicolumn{2}{|c|}{ Total } & \multicolumn{2}{|c|}{ Urban } & \multicolumn{2}{|c|}{ Rural } \\
\hline & AOR* & $95 \% \mathrm{CI}$ & AOR* & $95 \% \mathrm{CI}$ & AOR* & $95 \% \mathrm{CI}$ \\
\hline \multicolumn{7}{|l|}{ Mother's age } \\
\hline 15 - 19 years & 1.00 & & & & & \\
\hline 20-34 years & 1.52 & $(0.99-2.33)$ & 1.32 & $(0.68-2.55)$ & 1.89 & $(1.17-3.07)$ \\
\hline 35 - 49 years & 2.70 & $(1.74-4.19)$ & 2.33 & $(1.19-4.55)$ & 3.48 & $(2.05-5.91)$ \\
\hline \multicolumn{7}{|l|}{ Mother's education } \\
\hline $\begin{array}{l}\text { Primary or less } \\
\text { education }\end{array}$ & 1.00 & & & & & \\
\hline Secondary education & 1.69 & $(1.50-1.92)$ & 1.76 & $(1.50-2.07)$ & 1.50 & $(1.24-1.82)$ \\
\hline Higher education & 2.64 & $(2.25-3.12)$ & 2.69 & $(2.19-3.29)$ & 2.46 & $(1.86-3.26)$ \\
\hline \multicolumn{7}{|l|}{ Mother's occupation } \\
\hline Unemployed & 1.00 & & & & & \\
\hline Employed & 1.11 & $(0.99-1.24)$ & 1.18 & $(1.03-1.36)$ & 0.94 & $(0.79-1.12)$ \\
\hline
\end{tabular}




\section{Place of residence}

$\begin{array}{lll}\text { Urban } & 1.00 & \\ \text { Rural } & 0.71 & (0.63-0.79)\end{array}$

\section{Household economic} status

Quintile 1
Quintile 2
Quintile 3
Quintile 4
Quintile 5
mplication during
egnancy

1.00

Any complication

1.00

1.82

$$
(1.42-2.33)
$$

1.74

$(1.06-2.88)$

1.83

(1.37 - 2.45)

2.57

(2.02 - 3.26)

2.46

(1.54 - 3.92)

2.75

(2.06 - 3.67)

3.50

(2.76 - 4.43)

3.51

(2.21 - 5.58)

3.46

(2.59-4.64)

4.98

(3.92 - 6.34)

5.23

(3.28 - 8.35)

4.20

(3.09 - 5.72)

\section{Complication during
pregnancy}

arity

$\begin{array}{ll}1 & 1.00 \\ 2-3 & 0.76 \\ \geq 4 & 0.55\end{array}$

2.13

$(1.82-2.50)$

2.58

$(2.16-3.09)$

1.00

0.76

$(0.67-0.85) \quad 0.80$

(0.69- 0.93)

0.65

(0.54-0.78)

Pregnancy

$(0.46-0.66) \quad 0.59$

(0.47- 0.73)

0.47

(0.35-0.63)

$\begin{array}{ll}\text { Aterm } & 1.00 \\ \text { Preterm } & 1.17 \\ \text { Postterm } & 2.16\end{array}$

1.00

2.16

(1.06 - 1.30)

1.16

(1.02 - 1.32)

1.21

(1.03 - 1.41)

$(1.36-3.45)$

2.34

(1.23 - 4.48)

1.87

(1.05 - 3.33)

\section{Twin}

No

1.00

Yes

5.57

$(3.88-8.02)$

5.09

$(3.17-8.16)$

6.44

$(3.63-11.43)$

Note: Estimates are also adjusted for province (not shown in the table)

\section{Discussions}

There were higher caesarean section rates among urban and lower rates among rural and the rates varied between provinces. The rates in urban area Indonesia was exceeds the World Health Organization(WHO) recommendation limit of 10 percent(The World Health Organization, 2015). In addition, the WHO data analysis results in 159 countries from 1980 to 2012 show that the proportion of caesarean section above 10 percent was not associated with a reduction in maternal and neonatal deaths (Ye et al., 2016). While caesarean section rates in urban area nearly bellow recommendation limit of 5 percent.

This study shows the inequalities of caesarean section rates between urban and rural within province remain. Low level of caesarean section rates and wider inequalities between urban and rural in several provinces, such as Papua and Maluku may be due to lack of skilled health staff and health infrastructure, including inavailabilityof emergency obstetric care. Indonesian Health Facility Survey (RIFASKES) showed that nearly 50 percent of public hospital was not accredited and the percentage much higher in Papua and Maluku, accounted for 78\% and 93\%, respectively(Badan Penelitian dan Pengembangan Kesehatan Kemenkes RI, 2011). Absence of obstetrician and surgeon also lead to lower caesarean section rates, where only $29 \%$ of public hospital in Maluku have obstetrician and nearly half did not have surgeon. Other reasons for low level of caesarean section rates includes economic reasons, urge to vaginal delivery(Chigbu and Iloabachie, 2007; Boatin et al., 2018). Geographical barriers also lead to inequality in accessing emergency obstetric care, where most of Maluku province area were consist of oceans while Papua mainly mountains(Hodge et al., 2014). 
This study shows an increasing trend in the proportion of caesarean section delivery in mothers along with higher level of socioeconomic status. The results of a multivariate analysis showed that women with the richest economic status were four times more likely to have caesarean section deliveries. This is in line with previous research in the continued analysis of RISKESDAS 2010(Suparmi and Basuki, 2011) and other studies in Canada(Leeb et al., 2005), Ethiopia(Gebremedhin, 2014) and China(Sufang et al., 2010) and data analysis of DHS in 26 countries(Calvello et al., 2015). Higher rates of caesarean section in richest quintile were likely due to higher proportion of elective caesarean section. Studies conducted in Jakarta show the proportion of elective caesarean delivery was higher than the proportion of emergency sectional delivery(Andayasari et al., 2015). Several factors that lead to higher rates of caesarean section includes individual factors such as urge to caesarean delivery because of fear of pain during labor, fear of death, cosmetic appearance and sexual functioning. Cultural factor also may lead to high caesarean section rates such as choosing the date of the baby's delivery on the basis of luck and fate for the future(Boatin et al., 2018). Health system support may escalate caesarean section rates such as higher financial incentives and lower tolerance to any complication in health facility.

Several studies have shown that women with a history of caesarean section without a medical indication of elective caesarean section have a higher risk of abnormal placental attachment in the uterine or uterine part of the uterine wall part of the uterus (placenta accreta) at subsequent births, this can lead to heavy bleeding during labor(The Royal Australia and New Zealand College of Obstetrician and Gynaecologist., 2016). In addition, caesarean section delivery has a cost burden(Borghi et al., 2003), lengths of hospitalization and a higher risk of illness when compared with a normal delivery(Souza et al., 2010; Siti Maisyaroh Fitri Siregar and Jemadi, 2013).

This study also showed that mothers aged 36-49 years were three times more likely to have caesarean section delivery than women aged 15-19 years. This is because in mother age over 35 years have a risk of complications in childbirth. This finding is in line with a study by Zhife He et al in China that the proportion of caesarean section delivery in mothers older than 35 years is greater than for normal delivery(He et al., 2016).

The results of multivariate analysis showed parity associated with caesarean section, where caesarean section was more prevalent in the first pregnancy. This finding is in line with research conducted in China(Feng et al., 2012) and Australia(Toohill et al., 2014). The psychological condition of expectant mothers and there is fear of childbirth pain was lead to higher rates of caesarean section(Toohill et al., 2014). However, this finding was in contrast to studies in Africa that show the proportion of caesarean section increased with increasing parity(Gebremedhin, 2014). The higher parity is associated with risk of complications in labor. This difference is possible because of the high proportion of sectional births in Indonesia.

This study had potential limitation to be considered in interpreting the findings. Firstly, this inequality analysis was based on simple measure of ratio and difference which can be use for clarity and ease of understanding. Secondly, data on caesarean section rates were based on mothers self-reporting from a cross-sectional survey. Thirdly, the survey did not have detailed information on some predictors related to caesarean section, such as, on placenta previa, breech position, cord prolapsed, failure to progress in labor, repeated caesarean sections, cephalopelvic disproportion, fetal distress, birth defects, and demand to have caesarean section from the subjects as well as from the respective medical doctors. However, despite these limitations, this study had a large sample size $(n=49045)$ and the data were nationally representative and can be aggregated into province and districts level data.

\section{Conclusion}

The result of this study shows the sub-national inequality of caesarean section rates between urban and rural. Additionally, factors associated with caesarean section delivery in urban and rural include pregnancy complications, post-term pregnancy, multiple births/twin, maternal age over 35 years, and high socioeconomic status. Overall, urban more likely had higher caesarean section rates. This study suggest that it is necessary to 
ensure that pregnant women living in rural area have better access to caesarean section and increase alertness especially for mothers with high level of economic status in urban area not to conducting caesarean section without medical indication. In addition, there is a need for health promotion related to the side effects of caesarean section without medical indication.

\section{Acknowledgements}

The authors would like to acknowledge the National Institute for Health Research and Development for providing the data. The authors also wish to express their most sincere gratitude to Dr. Julianty Pradono for all her comments during paper development.

\section{References}

Andayasari, L., Muljati, S., Sihombing, M., Arlinda, D., Opitasari, C., Fajar, D. and Widianto, M. (2015) 'Proporsi Seksio Sesarea dan Faktor yang Berhubungan dengan Seksio Sesarea di Jakarta', Buletin Penelitian Kesehatan, 43(2), pp. 105-116.

Badan Penelitian dan Pengembangan Kesehatan Kemenkes RI (2011) Laporan Riset Fasilitas Kesehatan (Rifaskes) 2011. Jakarta.

Betrán, A. P., Ye, J., Moller, A.-B., Zhang, J., Gülmezoglu, A. M. and Torloni, M. R. (2016) 'The Increasing Trend in Caesarean Section Rates: Global, Regional and National Estimates: 1990-2014.', PloS one, 11(2), p. e0148343. doi: 10.1371/journal.pone.0148343.

Boatin, A. A., Schlotheuber, A., Betran, A. P., Moller, A.-B., Barros, A. J. D., Boerma, T., Torloni, M. R., Victora, C. G. and Hosseinpoor, A. R. (2018) 'Within country inequalities in caesarean section rates: observational study of 72 low and middle income countries', $B M J, 360$.

Borghi, J., Bastus, S., Belizan, M., Carroli, G., Hutton, G. and Fox-Rushby, J. (2003) 'Costs of publicly provided maternity services in Rosario, Argentina', Salud Publica de Mexico, 45(1), pp. 27-34.

Calvello, E. J., Skog, A. P., Tenner, G. and Wallis, L. A. (2015) 'Applying the lessons of maternal mortality reduction to global emergency health', Bull World Health Organ, 93(January), pp. 417-423. doi: 10.2471/BLT.14.146571.

Chigbu, C. O. and Iloabachie, G. C. (2007) 'The burden of caesarean section refusal in a developing country setting', pp. 1261-1265. doi: 10.1111/j.1471-0528.2007.01440.x.

Feng, X. L., Xu, L., Guo, Y. and Ronsmans, C. (2012) 'Factors influencing rising caerarean section rates in China between 1988 and 2008', Bulletin of the World Health Organization, 90(1), pp. 30-39. doi: 10.2471/BLT.11.090399.

Gebremedhin, S. (2014) 'Trend and socio-demographic differentials of Caesarean section rate in Addis Ababa, Ethiopia: analysis based on Ethiopia demographic and health surveys data.', Reproductive Health. Reproductive Health, 11(1), p. 14. doi: 10.1186/1742-4755-11-14.

He, Z., Cheng, Z., Wu, T., Zhou, Y., Chen, J., Fu, Q. and Feng, Z. (2016) The Costs and Their Determinant of Cesarean Section and Vaginal Delivery: An Exploratory Study in Chongqing Municipality, China, BioMed Research International. doi: 10.1155/2016/5685261.

Hodge, A., Firth, S., Marthias, T. and Jimenez-Soto, E. (2014) 'Location matters: Trends in inequalities in child mortality in Indonesia. Evidence from repeated cross-sectional surveys', PLoS ONE, 9(7). doi: 10.1371/journal.pone.0103597.

Leeb, K., Baibergenova, A., Wen, E., Webster, G. and Zelmer, J. (2005) 'Are there socio-economic differences in caesarean section rates in Canada?', Healthcare policy, 1(1), pp. 48-54.

Siti Maisyaroh Fitri Siregar, R. and Jemadi (2013) 'Karakteristik ibu bersalin dengan sectio caesarea di Rumah Sakit Umum Daerah dr. Pirngadi Medan Tahun 2011-2012', Jurnal Gizi, Kesehatan Reproduksi dan Epidemiologi, 2(5).

Souza, J. P., Gülmezoglu, A., Lumbiganon, P., Laopaiboon, M., Carroli, G., Fawole, B., Ruyan, P. and WHO Global Survey on Maternal and Perinatal Health Research Group (2010) 'Caesarean section without medical indications is associated with an increased risk of adverse short-term maternal outcomes: the 2004-2008 WHO Global Survey on Maternal and Perinatal Health', BMC Medicine, 8(71), pp. 1-10. doi: 10.1186/1741-7015-8- 
71.

Statistics Indonesia (Badan Pusat Statistik-BPS), National Population and Family Planning Board (BKKBN), Departemen Kesehatan and Macro International. (2008) Indonesia Demographic and Health Survey 2007. Calverton, Maryland, USA.

Statistics Indonesia (Badan Pusat Statistik-BPS), National Population and Family Planning Board (BKKBN), Kementerian Kesehatan (Kemenkes-MOH) and ICF International (2013) Indonesia Demographic and Health Survey 2012. Jakarta: BPS, BKKBN, Kemenkes, and ICF International.

Sufang, G., Padmadas, S. S., Fengmin, Z., Brown, J. J. and Stones, R. W. (2010) 'Delivery settings and caesarean section rates in China', Children, 035808(August 2006), pp. 1-5. doi: 10.2471/BLT.06.035808.

Suparmi and Basuki, B. (2011) 'Signs or symptoms of complications in pregnancy and risk of caesarean section : an Indonesia national study', Health Science Journal of Indonesia, 2(2), pp. 71-76.

The Royal Australia and New Zealand College of Obstetrician and Gynaecologist. (2016) Caesarean Delivery on Maternal Request ( CDMR ).

The World Health Organization (2015) WHO Statement on Caesarean Section Rates. Geneva.

Toohill, J., Fenwick, J., Gamble, J. and Creedy, D. K. (2014) Prevalence of childbirth fear in an Australian sample of pregnant women, BMC Pregnancy and Childbirth. doi: 10.1186/1471-2393-14-275.

World Health Organization (2018) Intrapartum care for a positive childbirth experience. Available at: http://www.who.int/reproductivehealth/publications/intrapartum-care-guidelines/en/.

Ye, J., Zhang, J., Mikolajczyk, R., Torloni, M. R., Lmezoglu, A. M. and Betran, A. P. (2016) 'Association between rates of caesarean section and maternal and neonatal mortality in the 21st century: A worldwide population-based ecological study with longitudinal data', BJOG: An International Journal of Obstetrics and Gynaecology, 123(5), pp. 745-753. doi: 10.1111/1471-0528.13592. 


\section{Appendix}

Appendix Table 1 Urban and rural inequality of caesarean section rates by Province, Indonesia, RISKESDAS 2013

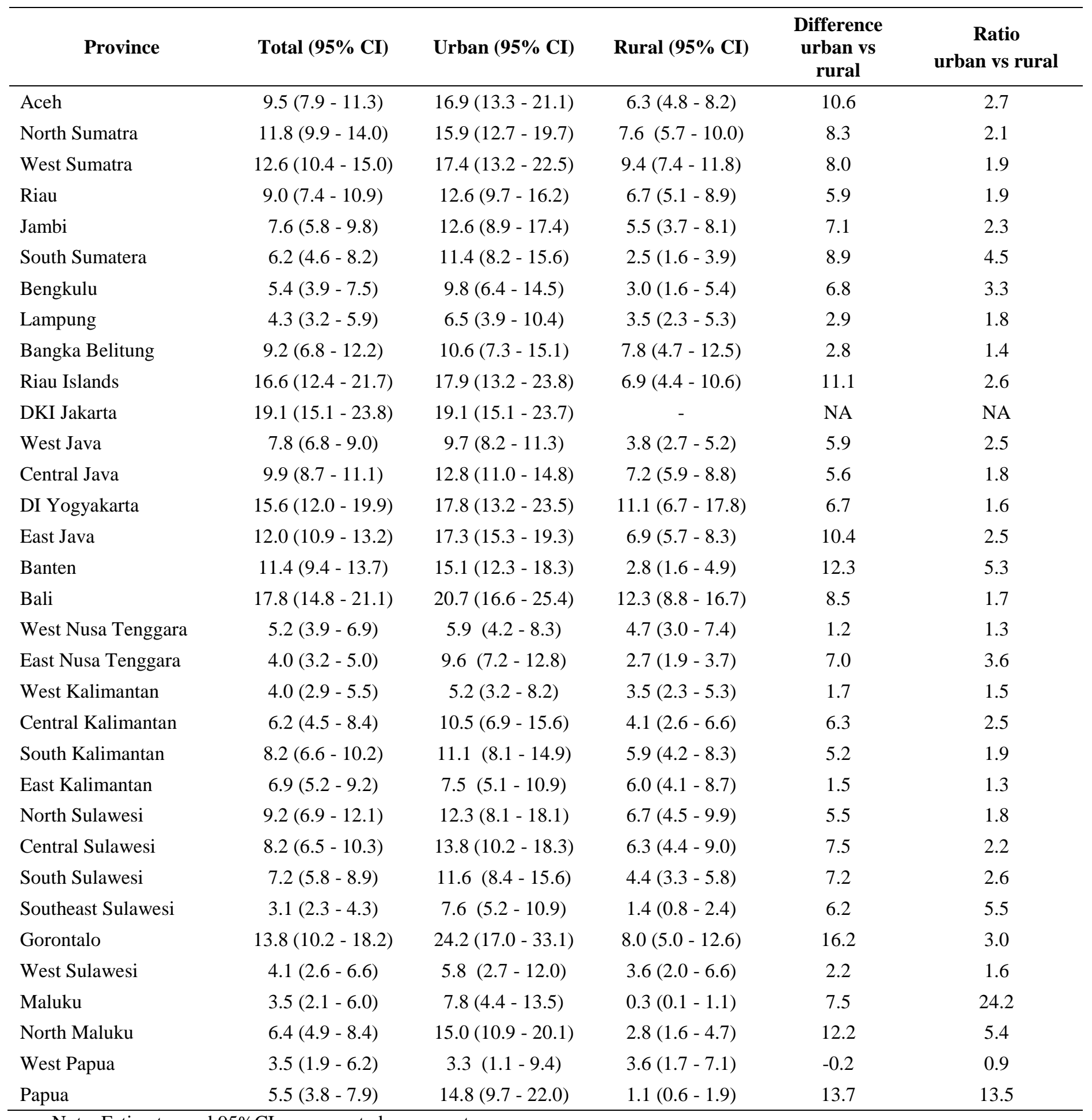

Note: Estimates and 95\%CIs are reported as percentages 